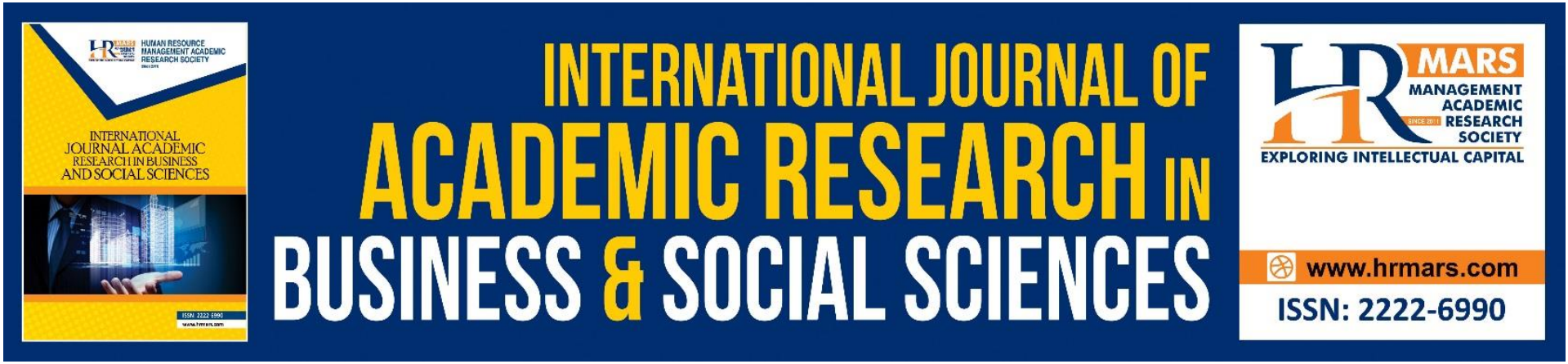

\title{
Tawjih Aqwal Mufassirin the Methods to Tawfiq Them
}

\section{Muhammad Auf Norzan Shah \& Mohd Faizulamri Mohd Saad}

To Link this Article: http://dx.doi.org/10.6007/IJARBSS/v11-i4/9718

DOI:10.6007/IJARBSS/v11-i4/9718

Received: 20 February 2021, Revised: 23 March 2021, Accepted: 06 March 2021

Published Online: 21 April 2021

In-Text Citation: (Shah \& Saad, 2021)

To Cite this Article: Shah, M. A. N., \& Saad, M. F. M. (2021). Tawjih Aqwal Mufassirin the Methods to Tawfiq Them. International Journal of Academic Research in Business and Social Sciences, 11(4), 715-724.

Copyright: (c) 2021 The Author(s)

Published by Human Resource Management Academic Research Society (www.hrmars.com)

This article is published under the Creative Commons Attribution (CC BY 4.0) license. Anyone may reproduce, distribute, translate and create derivative works of this article (for both commercial and non-commercial purposes), subject to full attribution to the original publication and authors. The full terms of this license may be seen at: http://creativecommons.org/licences/by/4.0/legalcode

Vol. 11, No. 4, 2021, Pg. 715 - 724

Full Terms \& Conditions of access and use can be found at http://hrmars.com/index.php/pages/detail/publication-ethics 


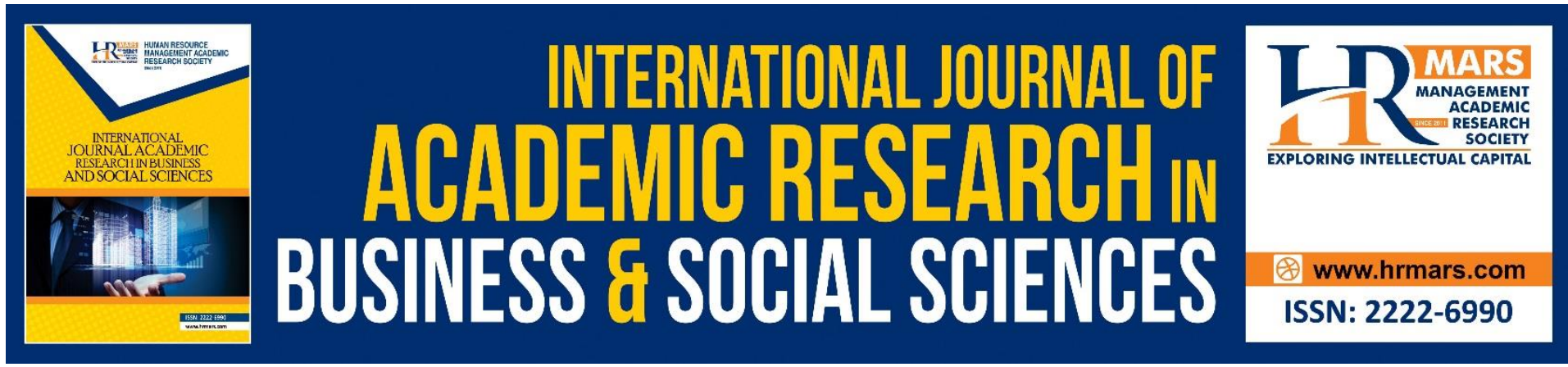

\title{
Tawjih Aqwal Mufassirin the Methods to Tawfiq Them
}

\author{
Muhammad Auf Norzan Shah \& Mohd Faizulamri Mohd Saad \\ Research Center for Quran and Sunnah, Faculty of Islamic Studies, National University of \\ Malaysia
}

\begin{abstract}
To tawjih the diverse aqwal mufassirin in the meaning of a verse and the methods of harmonizing it is an issue discussed in the discipline of usūl tafsir. This study focuses on masalik tawjih aqwal al-mufassirin (methods to tawjih the views of mufassirin) and compiling them. This study is important to provide an enlightenment on how researchers in the field of exegesis should cover the diversity of views of mufassirin so as not to ignore the views that are seen as contradictory, whereas there is a method to interpret it according to the discipline of usūl tafsir. The focus of the qualitative literature research in processing and analyzing this data is also seeks to present the methods of al-jam' and tawfiq that can be applied in the researcher's efforts to understand the true meaning of exegeses in line with the requirements of a verse.
\end{abstract}

Keywords: Tawjih, Aqwal Mufassirin, Tawfiq, Usūl Tafsir

\section{Introduction}

The scholars of aqwal mufassirin (saying of the exegete) according to the ultimate rules of usül tafsir (priciples of exegeses) by the scholars with manhaj ilmiyyah will find that there is an urgent need (dharūri) to pay attention to the places of ittifaq (concurrence, agreement) and ikhtilaf (differences/disagreement), classify those ikhtilaf, recognize the tawjih and their wujūh wurūd as well as the ways to tawfiq (harmonize/reconcillate) and tarjih between different views.

Therefore, a tafsir (exegesis) are within several situations, including a tafsir that is muttafaq calaih (agreed upon) in terms of lafz (pronunciation) and meaning, this tafsir is ijmac mufassirin (consensus of the exegete) in the text (nas), that is the exegesis of a verse with one meaning, for example such as their agreement in interpreting (المغضوب عليهم ) as the Jews and

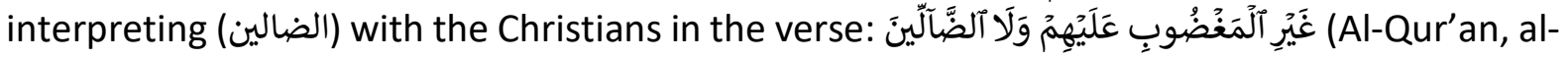
Fatihah 1:7) (Al-Khudairi, 1996), or the exegesis that have ikhtilaf (disagreement) upon it. The mukhtalaf (disagreed / difference upon) exegesis is divided into two (Al-Kalbi, 1995):

First: Different views but no contradictions between those views, in fact each has a right in the interpretation of the verse. The diversity of views here can be from the type of ikhtilaf tanaww $u^{c}$ which is the difference in terms of diversity such as the ikhtilaf in the use of parable to $t a^{c} b i r$ a term with different words or the ikhtilaf for an attribute where mufassir expresses an attribute not mentioned by other mufassir, or giving examples of some of the things 
included under the general instructions or a mufassir states the sabab nuzūl (occasions or circumstances of revelation) of a verse that are different from other mufassir, or a mufassir gives one of the meanings contained in the lafz musytarak (words that have the same spelling and pronunciation as well as showing more than one meaning) and others.

Second: Views in the exegesis of a verse, which are the difference in terms of lafz and meaning and it is not possible to compile and adjust at the same time because of the contradiction. Therefore, in this case it is necessary to do tarjih such as whether nasakh occurs or not in the multiple views of one verse. So it is not possible to compile except to choose one view and tarjih it. Similarly, the meanings of the lafz musytarak are prevented to be brought to at the same time. May also be included in this face, the shadhdhah opinions or views that are not accepted by the verses and contexts such as Baținiyyah tafsir.

\section{Statement of Problem}

In the discipline of usul figh, many authors have been involved in such debates from the basic point of view of the paths of al-jam ${ }^{c}$ wa al-tawfiq (gathering and harmonizing) between mukhtalaf in the debates of $a l-$ ta $^{c} a r u d h$ (contradiction) and tarjih between syariyyah, naskh, cam khas arguments (dalil) and the like. However, it requires many examples of the exegeses. According to (Al-Harbi, 2012), there has been no specific study and placement of principles on this matter from the point of view of exegeses. Thus it is an urgent need to put this matter together in a basic and practical manhaj so that a scholar of the kalam mufassirin (exegete comment) can get a true picture of the paths of al-jam ${ }^{c}$ and tawfiq between aqwal mufassirin and understand their wishes before performing tarjih between the aqwal.

\section{Research Methodology}

This study uses a qualitative research format in processing and analyzing data.

1. The paths to tawjih the views and to tawfiq between the views are compiled together with their dawabit from the books of tafsir, ulum al-Quran and usul fiqh, then the views of the mufassirin are formulated according to what is needed in the study.

2. Each masalik tawjih aqwal and tawfiq, is accompanied by examples from the exegeses so that the things to be conveyed are clear.

3. The influence and effect on the exegeses from the use of masalik tawjih aqwal and tawfiq, is highlighted through the examples mentioned.

4. The mufassirin's attention to this debate is also highlighted from the study of aqwal al-mukhtalafah in the exegeses.

5. The ilmiyyah foundation are used as a basis in strengthening the text (nas) and aqwal quoted from the original source.

\section{Discussion}

\section{First: The order of research on aqwal mufassirin}

It is the duty of the researcher of mufassirin views to follow the order below in studying the views of mufassirin:

\section{The first order: al-jam c and tawfiq (compile and harmonize)}

Al-jam ${ }^{c}$ and tawfiq between aqwal salaf in tafsir is a decree as long as it can be applied. Therefore, it is necessary to bring all the aqwal contained in the lafz and there is no obstacle to bring them all and do not lead to contradictions on the indication of zahir al-Qur'an because there is an ictibar on the whole of aqwal in the verse and do not leave anything out 
(Al-Sabt, 2000), because al-jam (compiling) is more important than tarjih according to the agreement of scholars (Al-Zarkasyi, 2008).

Abu Bakr al-Jassas ( $\mathrm{d}: 370 \mathrm{H}$ ) said that a lafz, if ihtimal for two things, then it is necessary to bring over the two things, and be both the required (things) (Al-Maliki, 2003) especially if the aqwal does not involve contradictions.

\section{The Second Order: (Taqdim Al-Awla) Prioritizing the More Important}

This sequence is specifically for the study of aqwal contained in the lafz, and there is no contradiction between it, nor does it contradict the text from the Qur'an and the Sunnah, only some parts are more important than the others, because the Qur'an and the dalalah of the lafz testified with one qawl or sunnah, testified for one or the Arabic language, or qarain (evidence) in the context or other reasons that set to precede one view (qawl), and which is not a decree by preceding one view, then set aside another view. This sequence occurs in part of the description of ikhtilaf al-tanawwuc (diversity) inherited from the salaf (Al-Harbi, 1996). There are many of such examples in the kalam mufassirin, it can be said that it is found in every exegeses of the verse. (Al-Harbi, 2012)

\section{The Third Order: Al-Tarjih}

If aqwal mufassirin cannot be compiled due to inconsistencies that are impossible to unite, then tarjih should be performed. It occurs in the case that the khilaf is from the type of تضاد which is the contradictory khilaf, then tarjih is done by adhering to the wujūh tarjih that is muctabar in the text itself or with qarinah and arguments outside it. That is, by adhering to the authentic aqwal and not the wrong or shadh. If the contradictory views arise from the same mufassir, then his final views are made ${ }^{i}$ tibar in a situation of equal validity, and if not, then the authentic or valid ones come first (Al-Zarkasyi, 2008).

Al-Syinqiti said(d: $1393 \mathrm{H})$ : ((It is a matter of knowing that al-jam ${ }^{c}$ is obligatory if possible, and if not, then should do tarjih)) (Al-Syinqiti, n.d.).

\section{Third: The Conditions of Al-Jam ${ }^{c}$ and Tawfiq between Aqwal Mufassirin}

According to (Al-Harbi, 2012), among the most important conditions for performing al-jam ${ }^{c}$ and tawfiq are:

1. The one who issues that view should be from the mufassirin who is muctabar among the scholars. Not all views of the exegeses author of al-Qur'an can be attributed to the views of the salaf in tafsir. This is because the deep salaf dalalah views in interpreting the text of the Qur'an, which are different from the views of most of the muta'akhirin (later ones).

2. The Aqwal to be compiled is tsabit from the speaker with an authentic and muctabar face.

3. Those who do al-jam ${ }^{c}$ should consist of those who are skilled.

4. The face collected between the aqwal shall be taken from the clues of the verse lafz and its context.

5. Shall the face that gathers aqwal from the point of view of the interpretation, includes the aqwal.

6. The aqwal collected according to its rules does not consist of fragile aqwal or that are far from dalalat nas qura'niy. 


\section{Tawjih Aqwal Mufassirin and the Methods to Tawfiq Them}

According (Al-Harbi, 2012), there are many methods to perform tawjih on aqwal mufassirin and to tawfiq them. Here are the most important rules:

\section{First: To Tawjih the Aqwal Mufassirin and to Tawfiq among Them by Takhrij (extracting and authenticating) Each Qawl of Qira'at:}

Qira'at brings a great impact and influence in the enrichment of the meanings of the verses of the Qur'an. Most qira'at disagreements in a verse will point to various meanings. Among the rulings of the scholars are: Two qiraat is like (the position of) two verses.(Al-Zarkasyi, 2008).

Zur bin Hubaish and Qatadah were among the first to analyze the various views of exegeses, tawjih it and tawfiq between them with the tawjih of each view according to the specific qira'at. In the exegesis of the word of Allah s.w.t. in surah al-Hijr verse 15: (ََقَالُوَاْ إِنَّمَا Which means: ((Surely they will (deny the truth) by saying: Our eyes have truly been dazzled)).

There are disagreements among the exegetes regarding the interpretation of this

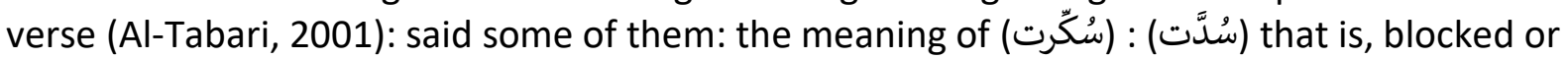
prevented. That is what Mujahid and al-Dahhak mentioned as well as other than both of them. Said others: ((the meaning of سُحِّرت iُ سُِّّت (bewitched)), so as Ibn 'Abbas and Qatadah said.

Both views of the interpretation of this verse consist of the qira'at disagreement on the lafz: (سُّكّترت): it is recited with tasydid on the letter kaf and to takhfif it. Recitation with takhfif kaf is the qira'at of Ibn Kathir, and the remaining of the seven qurra' recited with tasydid (Al-Qisi, 1984).

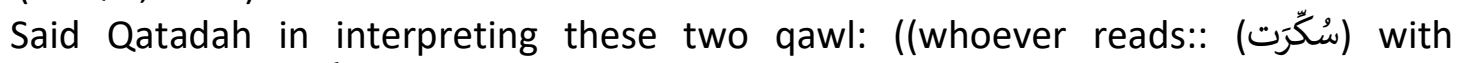

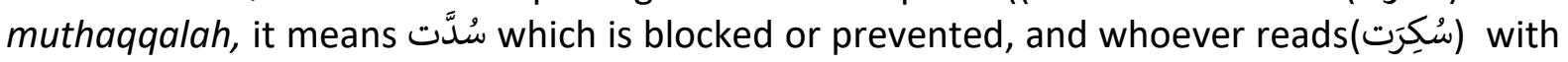
takhfif, then it will mean: سُحِرت that is, bewitched)) (Al-Tabari, 2001). (Al-Suyuti, 1951) praised al-jam $^{c}$ performed by Qatadah: ((This compilation (of views) of Qatadah is great and valuable)). And it is true that it is a valuable compilation that forms the basis for the manhaj study of aqwal salaf which varies in its exegesis and wujūh takhrij with what is contained in qira'at qura'niyyah.

\section{Second: To Tawjih the Aqwal Mufassirin and to tawfiq Among Them by Putting Each View of the Face according to Waqaf:}

This method is related to the knowledge of waqf and ibtida' because waqf is related to meaning and is a branch of it. Various places of waqf produces various meanings such as the various meanings of verses with various qira'at ('Asyūr, 1984).

Among the examples for the second path is as happened in the exegesis of the words of Allah swt:

(Al-Qur’an, Ali ' Imran 3:7)

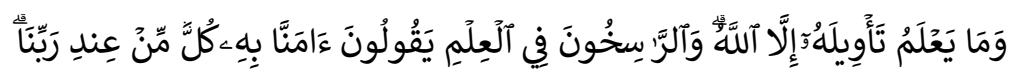

Which means: 
Whereas no one knows its Takwil (interpretation of its true meaning) except Allah. And those who remained steadfast in their knowledge of religion, said: "We believe therein, all is from our Lord."

The exegetes differ in interpreting this verse into two views:

First: No one knows ta'wil al-mutasyabih in the Qur'an except Allah S.W.T. This view is the view of some salaf: and so it is according to Saidatina 'Aisyah, Ibn 'Abbas, 'Urwah, 'Umar bin Abdul ' Aziz, Malik and others (Al-Tabari, 2001). And so as chosen by Ibn Jarir. Thus, waqaf

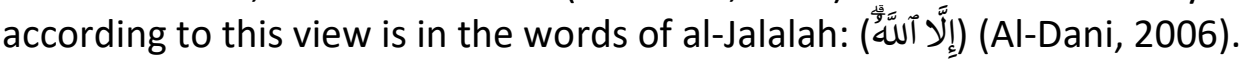

Second: Meaning: Even though no one knows the ta'wil except Allah S.W.T. and also those who remain steadfast and deep in their knowledge in religion, that is, people whose knowledge is rasikh (well-established) knows ta'wil al-mutasyabih and they say: "We believe in it, it all comes from our Lord". This is what a group of salaf said: and so did Ibn "Abbas, Mujahid, Rabic bin Anas (Al-Tabari, 2001) and many more of the mufassirin and the usūl scholars, they say: الخطاب بما لا يفهم بعيد (a speech that is not understood by (those) who are far away (from knowledge))(Ibn Kathir, 2000). According to this view, waqaf is on (Al-Dani, 2006). With this it can be seen that the waqf branches the meaning.

\section{Third: To Tawfiq the Aqwal Mufassirin by Putting Each View of Tafsir with Example}

One of the ways in which the Salaf interprets the lafz of the Qur'an is by interpreting a general lafz with some of its specialization by giving examples, because the example is included under the guidance of the lafz am. And such exegeses are not intended to specialize or limit the clues from other interpretations of the lafz am. ('Asyūr, 1984). There are many of such examples in the exegeses of the Qur'an by the salaf.

The Salaf took such an interpretation from the Prophet S.A.W. 'Uqbah bin 'Amir r.a.

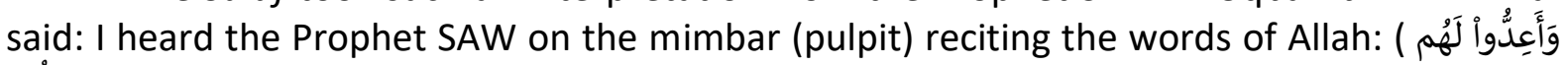
(Al-Qur'an, al-Anfal 8:60) which means: And prepare to oppose them (invading enemies) all kinds of strength that you can provide" then he said: "Know indeed that strength is archery! Know indeed that strength is archery! Know indeed that strength is archery! " (Al-Naisaburi, 1991). In this event, the Prophet S.A.W interprets strength with some of its details namely archery as an example and not as a specialization (Al-Tabari, 2001).

According to (Al-Zarkasyi, 2008) there are many views and disagreements of mufassirun in the meaning of the verse, and the author narrates in their exegeses with different parable of lafz because it is clearer on the part of the author, or because it is more appropriate to the situation of the person asking.

Among those included under this maslak is also various aqwal salaf on the sabab nuzūl of a verse whether the reasons are clear about it or unclear. So the differences are nothing more than examples that are under the meaning of the verse, as the verse includes a

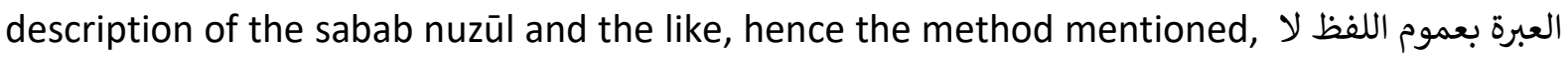
which means: 'lbrah (lessons) is seen from the generality of the lafz, not from a specific reason.

Ibn Taymiyyah said: As they said: Indeed the verse of zihar came down to women from the tribe of Thabit ibn Qais ibn Syammas, the verse $/ i^{c}$ an came down to ${ }^{~ U w a i m i r ~ a l-~}{ }^{c} A j l a n i$ or Hilal ibn Umayyah, and the verse al-Kalalah came down to Jabir ibn Abdullah and so on. Those 
who say so do not mean to set a specific law of a verse or specific to the individual mentioned, in fact it also involves the individual and those who are in the same situation with him, therefore their words, this verse comes down to this or that one, sometimes what is meant is the sabab nuzūl and sometimes the matter is in the verse although it is not the reason for the revelation of the verse. When this is understood, then their words: this verse comes down to such, does not deny the other view that says this verse comes down to such (Ibn Taimiyyah, 1972).

\section{Fourth: To Tawfiq the Aqwal Mufassirin by Compiling Them with the Kulli (Comprehensive) Meaning or Nature}

What is meant by this maslak is to bring a comprehensive meaning (kulli) that shares aqwal in its indication and set whether the meaning is musytarak (sharing) in one of the views stated in the verse or the aqwal shares the setting of meaning juzi'yyat (constituents) that is kulli. Among the examples of this uslub (style) is the various aqwal mufassirin (Ibn Kathir, 2000) in

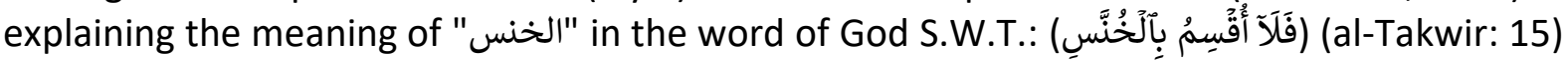
which means: ((So, I swear by those (stars) that recede)). Ali, Hasan and Qatadah interpret it as stars, which appear at night and sink during the day. Ibn Mas ${ }^{c} \bar{u} d$ interpreted it as wild bull. While Ibn 'Abbas, Mujahid and Sacid bin Jubair interpreted it as stag.

And the kulli meaning that brings together all the views is, each of them, the stars, the wild bull and the stag all disappear at some point in time and circumstances. The stars disappear during the day and appear at night, while the bull and the stag disappear when they see humans and reappear when they feel safe, therefore each of them disappears and appears alternately.

Ibn Jarir mentions: ((This is the comprehensive meaning (kulli) in his interpretation of this verse by saying: Verily Allah tacala mentions that He swears by something sometimes تخنس, that is disappearing, and sometimes walking and hiding at other times, كنوس : that is, taking refuge in the shelter, makanis according to Arabs is a place where wild bulls and stags are hiding... and there is no denying that this word is used in places where the stars is in the sky are found, and there is not a single indication in the verse that states a certain meaning. Therefore, it should be left as general, that is, everything that is خنوس in nature (disappears) sometimes and arises or appears at another time (Al-Tabari, 2001).

\section{Fifth: To Tawfiq the Aqwal Mufassirin by Bringing The Lafz To Its Whole Connotation In (Muțobaqah) Appropriateness, (Tadhammun) Implications And Iltizam (Commitment).}

In the kalam mufassirin there are many exegeses of a lafz with its corresponding exegesis is interpreted commonly, or with part of its meaning and it is a variety of uslüb description or explanation of the indication of a lafz. And there is no contradiction between the connotations of the three words: mutobaqah, tadhammun and iltizam.

The scholars of usul defined the listener's perfect understanding from the speaker's speech is named as dalalah muțobaqah. The listener's partial understanding is named as dalalah tadhammun, and the listener's understanding of a certain common thing (that is, with another meaning outside the essence of the lafz, but still has relevancy) is called dalalah iltizam (Al-Qarafi, 2004).

Among the examples of exegesis with lazim is the word of Abu Hayyan in the exegesis

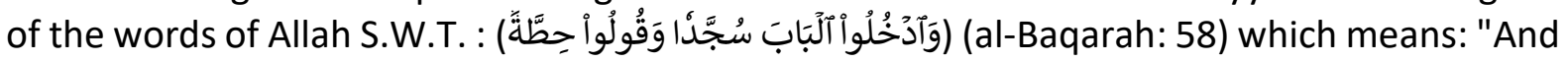


enter through the door by bowing (with humility); and (ask for forgiveness by) saying: 'O Allah forgive our sins ", he said: حِطة : on the wazan (scales) فِعلة from it is a masdar

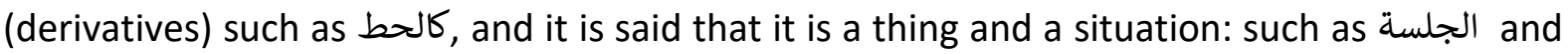
القعدة (sit down), and الحطالة is (removal). While according to Ahmad bin Yahya and Abban bin Taghlab, الحطة is repentance. This exegesis is an exegesis with the lazim, not a synonym (muradif), because whoever is removed from the sins then his repentance is accepted (Abu Hayyan, 2015).

\section{Sixth: To Tawfiqkan the Aqwal Mufassirin by Bringing the Verses on Its Entirety Due To Its Talazum (Connectivity)}

The spread of ideas about this maslak is due to the existence of a relationship between the details of the diversity of meanings in the interpretation of verses. It occurs when a lafz is brought over a meaning, usually there is other meaning or enter (another meaning) in it. It is possible to get the inspiration of some lawazim from the ma'ani contained in the nas qur'ani provided it preserves the original meanings in the dalalah (indication) of words and context and adheres to it. As it is compulsory that the common (connected) meaning does not get out of zahir dalalah verse because otherwise, there will surely be a lie on the Book of Allah S.W.T. (Al-Harbi, 2012).

Among the examples of this maslak is the exegesis of the word of Allah S.W.T..: إِنَّ ألَّذِي

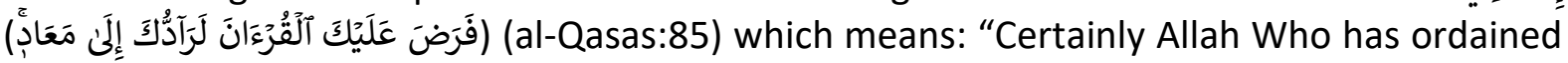
for you the Qur'an (O Muhammad) (i.e. ordered you to act on its laws and to preach it to others) will surely bring you back to the place which you love". According to (Ibn Kathir, 2000)

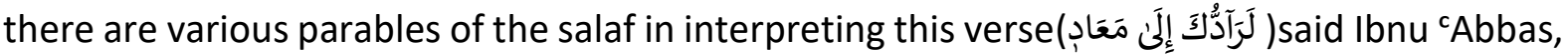
Abu Sacid al-Khudri, Mujahid, 'Ikrimah and other than them: its meaning is: لمصيرك إلى الجنة (the place where you end up in heaven).

From 'Ikrimah, 'Ato', Mujahid, al-Hassan and others: لرادك إلى يوم القيامة (will certainly bring you to the Day of Judgment.

From Ibnu cAbbas and Mujahid: لرادك إلى الموضع الذي خرجت منه وهو مكة (will certainly deliver you to the place where you came out of it, which is Mecca).

Tawjih for this aqwal, sometimes Ibn 'A Abbas interprets it by referring to Mecca, which is the opening of the city of Mecca which from the point of view of Ibn 'Abbas, it is a signal of the imminent death of the Prophet S.A.W. At another time, Ibn 'Abbas interpreted the word of Allah: (لَرَآَُّكَ إِلََّى مَعَاد) as death, and also with the meaning of the Day of Judgment that occurs after death, and sometimes with the meaning of heaven which is the reward and the place of end after fulfilling the trust of Allah S.W.T. (Ibn Kathir, 2000). And such examples are abundant in the words of mufassirin.

\section{Seventh: To Tawfiq the Aqwal Mufassirin by Bearing Musamma on All Its Attributes which is Interpreted with It}

This method is to justify the change of the parables of the mufassirin in the exegesis of a lafz to its various attributes that is, each mufassir mentions one attribute that is not mentioned by other mufassirs. This is a form of tanawwuc (diversity) in the parable and not a true khilaf (Ibn Taimiyyah, 1972), there are many of this examples in the kalam mufassirin. Among them is the exegesis of the words of Allah swt: (وَقَصَّر مَّشِيدٍ) (al-Haj:45) which means: "and lofty palace (left empty)". 'Ikrimah, Mujahid, 'Ato', Sacid bin Jubair interpret it with: ((بقصر مجصص :)) which means a white limestone walled palace, and it is a feature or property of a palace. 
Al-Dahhak interprets it with: (قصر طويل مرتفع)) which means an elongated and tall palace. And ارتفاع (height) are among the characteristics or properties of a palace. While Qatadah interprets it with: (قصر محصن)) (Ibn Kathir, 2000) means a palace fortified with a (strong) fort. And تحصين (fortify) are the characteristics or properties of a palace. So each view expressed is a property / feature that is different from the others. And in fact these views are mutually ittifaq (agreed) and not mukhtalafah.

All agreed that the reward/retribution of Allah S.W.T will be inflicted on the occupants of the magnificent palace whether the palace is strengthened, or the position of the palace is high or finely built, these will not save its occupants at all (from the reward/retribution).

\section{Eighth: To Tawfiq the Aqwal Mufassirin by Bringing the Lafz to the Whole Aqwal Because It Is Closer (in Meaning)}

This maslak is related to the mutabiq (identical) exegeses with the lafz (there is a connection in terms of the meaning of the lafz) from the language point of view. This is what is called tafsir lafz̦i, the books of a $^{c} a j i m$ al-lughawiyyah and the books of gharib al-Qur'an focused a lot on this type of exegeses.

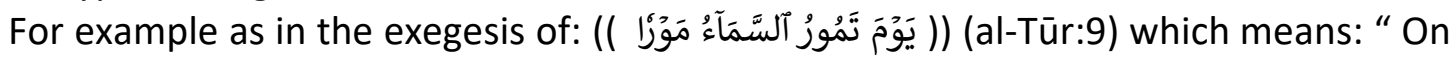
that Day the heaven (and its contents) will be convulsed to the utmost convulsion". The meaning of حركة is مَور that is movement, then both are close with the meaning المَور is a brief and fast movement))(Ibn Taimiyyah, 1972). He has also listed a number of qur'aniyyah lafz and their meanings which are interpreted with closer lafz, from the point of view of taqrib such as الوحي, ريب , تُبْْنَل and analyze the matter.

\section{Conclusion}

As a conclusion from this study, it can be concluded:

1. Aqwal salaf in tafsir has a deep dalalah in explaining the Qur'anic text that is not found elsewhere.

2. The salaf are concerned in preserving the condition of the recipient of their exegeses, therefore their aqwal is multipled because of the multiple conditions of the recipients and their multiple needs from the guidance of the Qur'an.

3. The diversion of the Salaf from interpreting the words of the Qur'an in accordance with its interpretation to the interpretation with examples and meanings is due to the reasons that is muctabar.

4. A study related to aqwal mufassirin should be done in stages as stated in this study that is by following the maratib al-nazor (sequence of observations) in aqwal mufassirin.

5. Diversifying the meaning of Qur'anic verses by bringing verses of all aqwal is more important than reducing them by leaving out some of them.

\section{References}

Al-Qur'an al-Karim

Abu Hayyan, M. (2015). Al-Bahr al-Muhit fi Tafsir Al-Qur'an Al-Azim (A. Al-Turki (ed.); Markaz Hajar.

Al-Dani, A. 'Amru. (2006). Al-Muktafa fi al-Waqf wa al-Ibtida (J. al-D. Syaraf (ed.)). Dar alSahabah li al-Turath bi Țanta.

Al-Harbi, H. A. (1996). Qawa'id al-Tarjih cinda al-Mufassirin Dirasah Nazoriyyah Tatbiqiyyah. Dar al-Qasim. 
Al-Harbi, H. A. (2012). Aqwal al-Mufassirin Tawjihiha wa Masalik al-Tawfiq Bainaha. Dar Kunuz Isybilia.

Al-Kalbi, M. (1995). Al-Tashil li 'Ulūm al-Tanzil. Dar al-Kutub al-I'Imiyyah.

Al-Khudairi, M. (1996). Al-ljmac fi al-Tafsir. Dar al-Waton li al-Nashr.

Al-Maliki, A. B. (2003). Ahkam al-Qur'an (M. 'Ato (ed.); Dar al-Kutub al-I'Imiyyah.

Al-Naisaburi, M. (1991). Sahih Muslim (Cet.Pertam). Dar al-Hadis.

Al-Qarafi, A. (2004). Syarh Tanqih al-Fusūl fi Ikhtisar al-Mahsūl fi al-Usūl (M. al-B. wa al-D. bi D. Al-Fikr (ed.)). Dar al-Fikr.

Al-Qisi, M. A. T. (1984). Al-Kasyf ${ }^{c}$ an Wujūh al-Qira'at al-Sab ${ }^{c}$ wa cllaliha wa Hujajiha (M. Ramaḍan (ed.); Muassasah al-Risalah.

Al-Sabt, K. (2000). Qawacid al-Tafsir Jamªn wa Dirasatan. Dar Ibn Affan.

Al-Suyuti, J. al-D. A. al-R. (1951). al-Itqan fi Ulum al-Quran. Mustafa Bab al-Halabi.

Al-Syinqiti, M. al-A. (n.d.). Aḍowa' al-Bayan fi Idoh al-Qur'an bi al-Qur'an. Majma' al-Fiqh alIslami Jeddah.

Al-Tabari, J. (2001). Tafsir al-Tabari Jami al-Bayan 'an Ta'wil Ayi al-Quran (A. bin A. M. AlTurki (ed.); Dar Hajr.

Al-Zarkasyi, B. al-D. (2008). Al-Burhan fi cUlūm al-Quran (M. A. al-F. Ibrahim (ed.)). Dar alTurath.

'Asyūr, M. al-Ṭahir. (1984). Al-Tahrir wa al-Tanwir. Dar al-Tunisiyyah li al-Nashr. Ibn Kathir, I. (2000). Tafsir al-Qur'an al-'Azim. Dar Ibn Hazm.

Ibn Taimiyyah, A. (1972). Muqaddimah fi Usūl al-Tafsir ('Adnan Zarzur (ed.). 